九州大学学術情報リポジトリ

Kyushu University Institutional Repository

\title{
Measuring the Export Subsidy Equivalents (ESEs) through Price Discrimination Generated by Exporting State Trading Enterprises
}

Suzuki, Nobuhiko

Faculty of Agriculture, Kyushu Unviersity

Kinoshita, Junko

Policy Research Institute, Ministry of Agriculture, Forestry, and Fisheries, Japan

Fujii, Toshiaki

Graduate School of Bioresource and Bioenvironmental Sciences, Kyushu Unviersity

Kaise, Harry M.

Cornell University

https://doi.org/10.5109/4684

出版情報：九州大学大学院農学研究院紀要.50 (2)，pp.743-751，2005-10-01. Faculty of Agriculture, Kyushu University

バージョン：

権利関係 : 


\title{
Measuring the Export Subsidy Equivalents (ESEs) through Price Discrimination Generated by Exporting State Trading Enterprises
}

\author{
Nobuhiro SUZUKI*, Junko KINOSHITA ${ }^{1}$, Toshiaki FUJII ${ }^{2}$ \\ and Harry M. KAISER ${ }^{3}$
}

\author{
Laboratory of Quantitative Analysis of Agribusiness Organization, Division of Industrial \\ Organization of Agribusiness, Department of Agricultural and Resource Economics, \\ Faculty of Agriculture, Kyushu University, Fukuoka 812-8581, Japan \\ (Received June 30, 2005 and accepted July 26, 2005)
}

\begin{abstract}
The Doha Round framework agreements state that all forms of export subsidies should be eliminated, which includes not only export subsidies through food aid and export credits, but also "consumer financed" ones through exporting STEs. Therefore, one needs a theoretical definition and practical measurements of "hidden" export subsidies unregulated under the current WTO rules. This paper proposes a basic definition for the "consumer financed" export subsidy equivalent (ESE) created by STEs' price discrimination among export markets as well as price discrimination between export and domestic markets. Examples of calculated ESE values are shown using the Canadian dairy STE with price discrimination between export and domestic markets and the Australian wheat STE with price discrimination among export markets. The ESE proposed here would provide a useful measurement of "consumer financed" export subsidies.
\end{abstract}

\section{INTRODUCTION}

Several exporting state trading enterprises (STEs) currently exist in the world, which act as export monopolies. ${ }^{4}$ Examples include the Canadian Dairy Commission (CDC), Canadian Wheat Board (CWB), Australian Dairy Corporation (ADC), Australian Wheat Board (AWB), and Fonterra (formerly New Zealand Dairy Board (NZDB)). One of the most important roles of these enterprises is the implementation of price discrimination between domestic and export markets with the goal of maximizing the total sales values for the country's producers. Another price discrimination technique used by exporting STEs is the export of goods with identical quality at different prices to different countries as a way to maximize pooled total revenues from export markets. When differential prices exist in markets, and pooled revenues from these markets are distributed to farmers, the system is equivalent to an export subsidy.

1 Policy Research Institute, Ministry of Agriculture, Forestry, and Fisheries, Japan

${ }^{2}$ Laboratoy of Quantitative Analysis of Agribusiness Organization, Division of Industrial Organization of Agribusiness, Department of Agricultural and Resource Economics, Graduate School of Bioresource and Bioenvironmental Sciences, Kyushu University

3 Department of Applied Economics and Management, Cornell University, USA

${ }_{4}$ The state-owned or private enterprises exporting by the single desk are referred to as the exporting STEs in this paper. The single desk means the authorized exclusive right for monopoly trading.

* Corresponding author (E-mail: suzukino@agr.kyushu-u.ac.jp) 
However, the price discrimination practices by STEs has not been classified as export subsidies that must be reduced according to previous WTO agreements, while mark-ups imposed by importing STEs are considered to be equivalent to tariffs, and are already regulated under the agreements. This exclusion of exporting STE price discrimination practices is unfair for importing and exporting countries using no STEs. Hence, these "hidden" export subsidies by STEs should also be in the negotiation table for the WTO.

On July 31,2004, progress was made in this regard with the agreement on the Doha Round Framework. The Doha Round framework agreements state that all forms of export subsidies should be eliminated, which includes not only export subsidies through food aid and export credits, but also export subsidies through exporting STEs. To make this operational, one needs a theoretical definition and a practical measurement of "hidden" export subsidies that are unregulated under the current WTO rules.

Indeed, the CDC's "special" milk class system, which creates substantially lower prices for milk used for exporting products, was already judged to be equivalent to export subsidy by the WTO court. Legal questions still remain as to whether other exporting STEs such as the CWB, ADC, AWB, and Fonterra are exempted from rules for reducing export subsidy schemes under the WTO agreements.

In examining the issue of whether existing STEs violate the WTO agreement, it is useful to have a theoretical and empirical measurement of the degree of market distortion caused by price discrimination practices of the STEs. Several studies have analyzed price discrimination by STEs, such as McCorriston and MacLaren (2000), Alston and Gray (2000), and Brooks and Schmitz (1999). However, a practical measure of market distortion caused by these enterprises has not yet been developed. For example, McCorriston and MacLaren (2000) assumed that all STEs are Cournot players. When the actual degree of market distortion created by the STE is in question, such analyses with an a priori assumption for the degree of imperfect competition are not enough.

Suzuki et al. (1993) proposed an imperfect competition model for price-discriminated oligopolistic markets. In this paper, a similar basic framework is used to develop a measure for the degree of market distortion caused by STEs' price discrimination between export and domestic markets, and price discrimination among different export markets. Our approach differs from McCorriston and MacLaren (2000) because we directly estimate the actual degree of market power using a model that can express any degree of market competition.

Following the discussion of our model, we then propose a basic definition for the export subsidy equivalent (ESE) created by STEs' price discrimination among different export markets as well as price discrimination between export and domestic markets. Examples of calculated ESE values are shown using the Canadian dairy STE with price discrimination between export and domestic markets, and the Australian wheat STE with price discrimination among different export markets.

\section{CONCEPTUAL FRAMEWORK}

The following simple model is useful for describing mechanisms to circumvent export subsidies generated by price discrimination between domestic and export markets through exporting STEs. Assume that an agency (or an exporting STE) has the exclusive 
authority to deal with the country's marketing of a certain product. Even if this agency is a monopoly within the country, it does not mean that the agency has monopoly power since it could be a price taker through competition with international rivals if imports are not restricted. It is assumed here that there are some import-restricting measures for the agency to enable domestic prices to rise above the world price. The role of the agency is to allocate the country's supply of the commodity to domestic and export markets so as to maximize total sales revenues as the consignment seller of the commodity collected from farmers. The necessary condition for this to occur is to equate marginal revenues from domestic and export markets. The agency distributes the proceeds back to farmers by paying them a weighted average price from sales to the domestic and export markets. Farmers are assumed to be price takers, so they produce at a point where their marginal production cost is equal to the blend price they receive. The export price is determined by equating total world supply and demand. The agency is assumed to be a price taker in the world market.

Based on these assumptions, Fig. 1 illustrates this market situation conceptually, where $P_{d}$ is the domestic price, $Q_{d}$ is domestic supply, $Q_{s}$ is total supply, $P_{b}$ is the blend price, $\mathrm{QR}_{\mathrm{d}}$ is foreign demand, and $\mathrm{QR}_{\mathrm{s}}$ is foreign supply. The intersection (point $\mathrm{C}$ ) of the marginal revenue line of domestic sales and a given $\mathrm{P}_{\mathrm{w}}$ level (the horizontal marginal revenue line of export sales) in Fig. 1 (right) is the point equalizing the perceived marginal revenues of domestic and export sales. Point $\mathrm{C}$ can be expressed mathematically as:

$$
\mathrm{P}_{\mathrm{d}}+\left(\partial \mathrm{P}_{\mathrm{d}} / \partial \mathrm{Q}_{\mathrm{d}}\right) \theta \mathrm{Q}_{\mathrm{d}}=\mathrm{P}_{\mathrm{w}}
$$

or

$$
\mathrm{P}_{\mathrm{d}}(1-\theta / \mathrm{E})=\mathrm{P}_{\mathrm{w}}
$$

where $\theta(0 \leq \theta \leq 1)$ is a degree-of-market-power parameter, $\mathrm{E}$ is the price elasticity of domestic demand in absolute value or, $-\left(\partial \mathrm{Q}_{d} / \partial \mathrm{P}_{\mathrm{d}}\right)\left(\mathrm{P}_{\mathrm{d}} / \mathrm{Q}_{\mathrm{d}}\right)$. The left-hand side of equation (1) is the perceived marginal revenue from domestic sales. Because the agency is a price setter in the domestic market, the domestic price is expected to decrease by $\left(\partial \mathrm{P}_{\mathrm{d}} /\right.$ $\left.\partial Q_{d}\right) \theta$ when the domestic sales volume increases by one unit. Therefore, the decrease in total revenue from domestic sales is $\left(\partial \mathrm{P}_{\mathrm{d}} / \partial \mathrm{Q}_{\mathrm{d}}\right) \theta \mathrm{Q}_{\mathrm{d}}$. Accordingly, the perceived additional revenue from a unit volume increase in domestic sales is $\mathrm{P}_{d}+\left(\partial \mathrm{P}_{\mathrm{d}} / \partial \mathrm{Q}_{\mathrm{d}}\right) \theta \mathrm{Q}_{\mathrm{d}}$ as shown in equation (1). The right-hand side of equation (1) is the perceived marginal revenue from export sales. It is expected to be constant regardless of changes in export volume because the model assumes that the agency is a price taker in the export market. The value for $\theta$ is affected by the degree of border protection. The agency could have monopoly power shown by $\mathrm{P}_{d}(1-1 / \mathrm{E})=\mathrm{P}_{\mathrm{w}}$ when imports are prohibited, while the agency could become a price taker in the domestic market (i.e., $P_{d}=P_{w}$ ) when there is no border protection.

The agency allocates its domestic sales up to the level, $Q_{d}$, to achieve the domestic price $\left(\mathrm{P}_{\mathrm{d}}\right)$ determined at the intersection (point $\mathrm{A}$ ) of the demand curve and $\mathrm{Q}_{\mathrm{d}}$ on the $\mathrm{X}$-axis. Domestic production is determined at the intersection (point $\mathrm{E}$ ) of the supply curve and the pooled price line. The pooled price line can be expressed mathematically as:

$$
P_{b}=\left[P_{d} Q_{d}+P_{w}\left(Q_{s}-Q_{d}\right)\right] / Q_{s}
$$


When equilibrium is achieved at a given world price $\left(\mathrm{P}_{\mathrm{w}}\right)$, the agency's export volume $\left(Q_{s}-Q_{d}\right)$ in Fig. 1 (right) is equal to the import volume $\left(Q_{d}-Q_{s}\right)$ in the rest of world shown in Fig. 1 (left). When both domestic and world markets are perfectly competitive, equation (1) becomes $\mathrm{P}_{\mathrm{d}}=\mathrm{P}_{\mathrm{w}}\left(=\mathrm{P}_{\mathrm{b}}\right)$ since $\theta=0$, and $\mathrm{P}_{\mathrm{w}}{ }^{*}$ in Fig. 1 indicates the perfectly competitive level. It should be noted that the competitive world price, $\mathrm{P}_{\mathrm{w}}{ }^{*}$, is higher than the current world price, $P_{w}$, with price discrimination by the agency. The agency causes the world price to be lower because it restricts domestic sales to achieve a higher domestic price and expands export sales, which generate a lower world equilibrium price.

Since producers receive the pooled price, $\mathrm{P}_{\mathrm{b}}$ with the export price, $\mathrm{P}_{\mathrm{w}}$, being lower than $P_{b}$, the amounts shown by the rectangle BCDE area in Fig. 1 (right) are equivalent to export subsidies. Under this scheme, consumers pay the entire amount of the subsidy, which is illustrated in Fig. 1 by the BCDE area being equal to the $P_{d} P_{b} B A$ area. In the case of the ordinary export subsidy regulated under the WTO, the government or taxpayers pay the BCDE area. Therefore, the $\mathrm{P}_{\mathrm{t}} \mathrm{P}_{\mathrm{b}} \mathrm{BA}$ or BCDE area can be defined as a "consumer financed" export subsidy equivalent (ESE) (Schluep, 1999). In this case,

$$
\mathrm{ESE}=\mathrm{Q}_{\mathrm{e}}\left(\mathrm{P}_{\mathrm{b}}-\mathrm{P}_{\mathrm{w}}\right)=\mathrm{Q}_{\mathrm{d}}\left(\mathrm{P}_{\mathrm{d}}-\mathrm{P}_{\mathrm{b}}\right),
$$

where $Q_{\mathrm{e}}=\mathrm{Q}_{\mathrm{s}}-\mathrm{Q}_{\mathrm{d}}$.

From the viewpoint of economic welfare, the "consumer financed" export subsidy may be worse than the ordinary one (Alston and Gray, 2000). In Fig. 1, when the producer price $\mathrm{P}_{\mathrm{b}}$ is provided by the ordinary export subsidy, the export quantity is $\mathrm{FE}$, the export price is $\mathrm{P}_{\mathrm{w}}{ }^{\prime}$, and the government expenditure is the rectangle FGHE. In this case, welfare losses compared to a perfectly competitive free market are the sum of the four black triangles, which are smaller than those in the case of "consumer financed" export subsidy by the sum of the three gray trapezoids. ${ }^{5}$

The "consumer financed" ESEs are larger as the value for $\theta$ becomes larger ceteris paribus, as shown by:

$$
\mathrm{ESE}=\left(\theta \mathrm{P}_{\mathrm{d}} \mathrm{Q}_{\mathrm{d}} \mathrm{Q}_{\mathrm{e}}\right) /\left(\mathrm{E} \mathrm{Q}_{\mathrm{s}}\right)
$$

from equations (2) and (4). Therefore, $\theta$ is also an indicator of the magnitude of ESEs.

Although the model presented above explains ESEs by price discrimination between domestic and export prices, the model can also be used for price discrimination among export markets. The model can be easily extended in this direction by introducing cases where foreign consumers also pay the ESEs. Fig. 2 illustrates several cases using three countries. Case (a) is where domestic consumers finance the two foreign markets; Case (b) is where domestic consumers and consumers in foreign country 1 finance foreign country 2; Case (c) is where consumers in foreign country 1 finance foreign country 2; and Case (d) is where consumers in foreign country 1 finance the domestic market and foreign country 2 . In all cases, the black areas subsidize the gray areas. Therefore, a general "consumer financed" ESE can be defined by:

\footnotetext{
${ }^{5}$ No tax collecting costs are assumed here.
} 


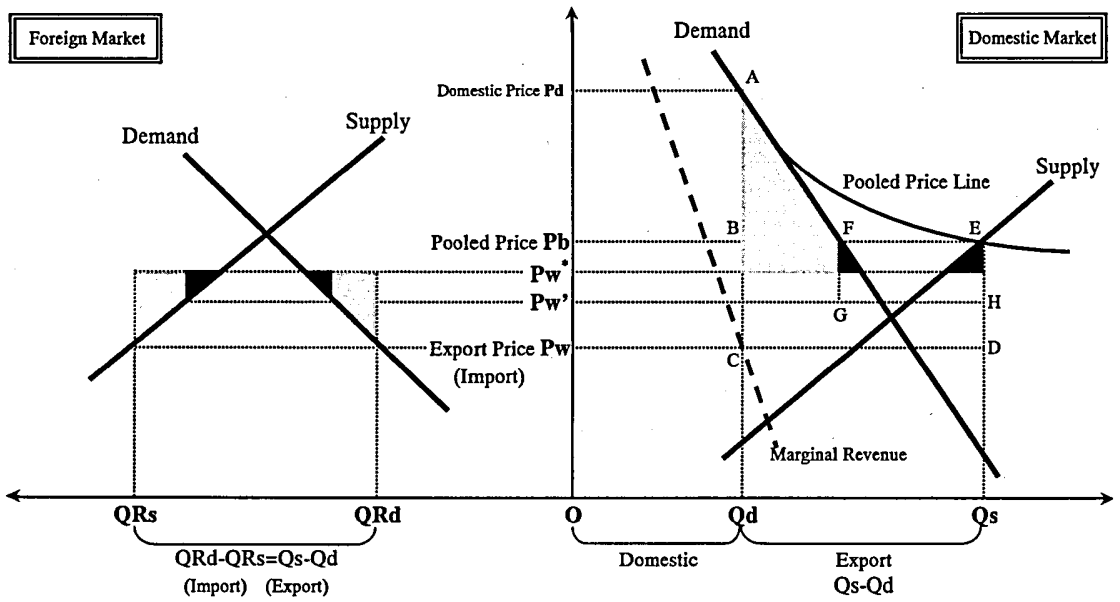

Fig. 1. Export Subsidy Equivalents (Two-Region Model)

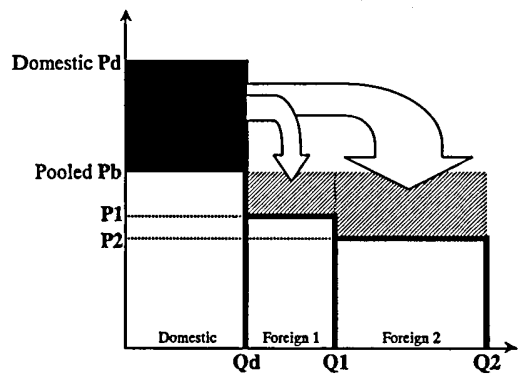

(a) Financed by Domestic Consumers

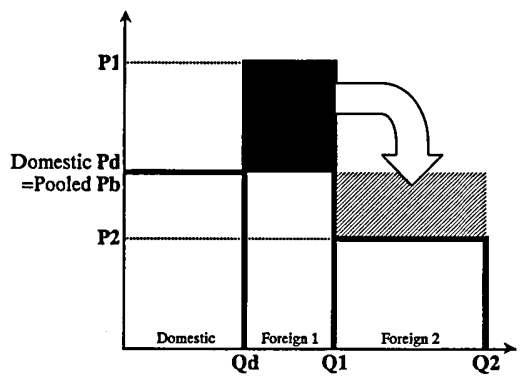

(c) Financed by Foreingn Consumers (Domestic Price=Pooled Price)

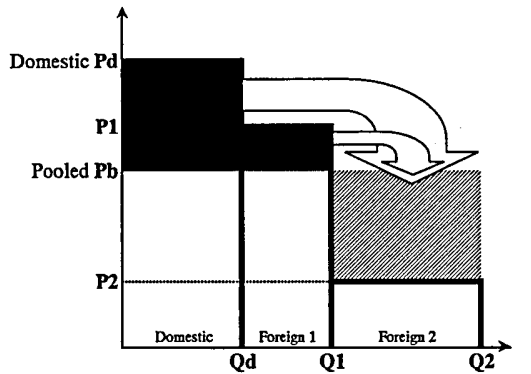

(b) Financed by Domestic and Foreign Consumers

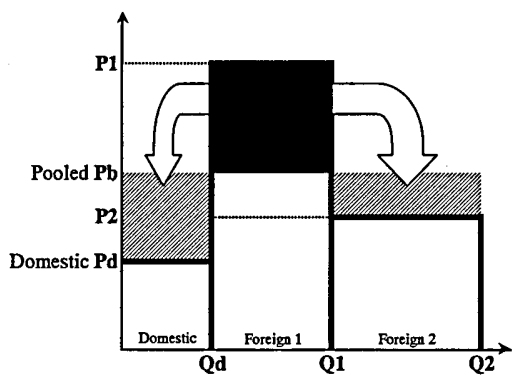

(d) Financed by Foreign Consumers (Domestic Price < Pooled Price)

Fig. 2. Four Types of Export Subsidy Equivalents 


$$
\mathrm{ESE}=\sum\left|\mathrm{P}_{\mathrm{j}}-\mathrm{P}_{\mathrm{b}}\right| \mathrm{Q}_{\mathrm{j}} / 2
$$

where $P_{j}$ is the price received from the jth country net of transaction costs; $P_{b}$ is the pooled price; $Q_{j}$ is the quantity sold in the jth country. Using this formula enables us to calculate any "consumer financed" ESEs with country-by-country export quantities and prices, we can extend the ESE calculation to any cases.

In Case (c), the weighted average price of export sales paid to farmers is equal to the price farmers receive from domestic sales. This should be true of the current AWB, which lost its control over domestic sales, although it is still a price setter in export markets. Price-taking farmers must allocate their products between the domestic market and the AWB so as to achieve the condition that the average export price is equal to the price they receive from domestic sales (Gropp et al., 2000).

\section{EXAMPLES OF CALCULATED EXPORT SUBSIDY EQUIVALENTS}

\section{Data}

One can use the above model with estimates of demand elasticities, price and volume data to measure the market distortions caused by existing STEs in Canada, Australia, and New Zealand. Data for the price elasticity of demand for each product comes from the estimates used by the U.S. Department of Agriculture's SWOPSIM model (Roningen and Dixit, 1989), and Ohga and Yanagishima (1996). Domestic supply $\left(Q_{s}\right)$, export volume $\left(Q_{e}\right)$, and export price $\left(P_{w}\right)$ data are available from FAO (2000). The domestic price $\left(P_{d}\right)$ data are available for Canadian butter and skim milk powder because the CDC support price is announced. These data are shown in Table 1.

Although the CWB, ADC, AWB, and Fonterra do not announce their selling prices to domestic and different export markets, we can collect them from FAO (2000) and each country's import statistics. For example, related to Case (c) in Fig. 2, Fujii (2005) collected data on the AWB. Fujii (2005) found that the Australian domestic wheat price is very close to the average export price based on FAO (2000), which supports the theoretical expectation mentioned above. In addition, each country's imported wheat price from Australia net of transportation costs gives us the Australian export price by country. Fujii (2005) found that the export price to Japan is higher than other countries' and the export prices to other countries are very similar. Based on these findings, Fujii (2005) calculated ESEs for the AWB by considering that the differences among export prices to other countries are negligible and Japanese consumers pay the ESEs. These data are shown in Table 2.

\section{Results}

Table 1 shows the estimated market-power-parameters $(\theta \mathrm{s})$ and the export subsidy equivalents (ESEs) for the Canadian dairy STE. Estimated market power parameters indicate that none of the Canadian dairy sales has exerted pure monopoly power, which is reflected by the estimated values of $\theta$ s being less than 1 (recall that $\theta=0$ for perfect competition and $\theta=1$ for monopoly). Since the estimates of $\theta$ are non-zero for all three products, there is empirical evidence that these enterprises are exerting some market power through their price discrimination schemes used to subsidize exports. Total "con- 
Table 1. Examples of Export Subsidy Equivalent (ESE) Measures for Canadian Dairy Products

\begin{tabular}{|c|c|c|c|c|c|c|c|c|c|}
\hline \multirow{4}{*}{ Commodit } & \multicolumn{6}{|c|}{ Data } & \multicolumn{3}{|c|}{ Calculation } \\
\hline & $\begin{array}{c}\text { Domestic } \\
\text { Production } \\
\text { (1998) }\end{array}$ & $\begin{array}{l}\text { Export } \\
(1998)\end{array}$ & $\begin{array}{l}\text { Domestic } \\
\text { Price } \\
\text { (1998) }\end{array}$ & $\begin{array}{l}\text { Export } \\
\text { Price } \\
(1998)\end{array}$ & $\begin{array}{c}\text { Pooled } \\
\text { Price }\end{array}$ & $\begin{array}{c}\text { Price Elasticity of } \\
\text { Domestic Demand } \\
\text { (Absolute Value) }\end{array}$ & $\begin{array}{l}\text { degree-of- } \\
\text { market-power } \\
\text { parameter }\end{array}$ & ESE & $\begin{array}{l}\text { ESE per } \\
\text { unit }\end{array}$ \\
\hline & $(\mathrm{t})$ & $(\mathrm{t})$ & $(\$ / t)$ & $(\$ / t)$ & $(\$ / t)$ & & & (million \$) & $(\$ / t)$ \\
\hline & Qs & Qe & $\mathrm{Pd}$ & $\mathrm{Pw}$ & $\mathrm{Pb}$ & $\mathrm{E}$ & $\begin{array}{c}\theta \\
=\mathrm{E}(1-\mathrm{Pw} / \mathrm{Pd})\end{array}$ & $\begin{array}{c}\text { ESE } \\
=(\mathrm{Pb}-\mathrm{Pw}) \mathrm{Qe}\end{array}$ & $\mathrm{Pb}-\mathrm{Pw}$ \\
\hline Butter & 90,600 & 12,077 & 3,700 & 2,145 & 3,493 & 0.70 & 0.29 & 16.28 & 1,348 \\
\hline NDM & 69,700 & 34,352 & 3,063 & 1,442 & 2,264 & 0.50 & 0.26 & 28.24 & 822 \\
\hline Cheese & 351,620 & 29,306 & 4,922 & 3,446 & 4,799 & 0.72 & 0.22 & 39.65 & 1,353 \\
\hline
\end{tabular}

Notes. The quantities and prices other than domestic prices are from FAO (2000), and the elasticities from the SWOPSIM model.

The CDC purchase price are used for domestic prices. Pooled prices are calculated by $\mathrm{Pb}=(\mathrm{PdQd}+$ PwQe)/Qs.

Table 2. Examples of Export Subsidy Equivalent (ESE) Measures for Australian Wheat Exports

\begin{tabular}{|c|c|c|c|c|c|c|c|c|c|c|}
\hline \multirow{4}{*}{ Year } & \multicolumn{7}{|c|}{ Data } & \multicolumn{3}{|c|}{ Calculation } \\
\hline & $\begin{array}{c}\text { Total } \\
\text { Exports }\end{array}$ & $\begin{array}{l}\text { Total } \\
\text { Export } \\
\text { Price }\end{array}$ & $\begin{array}{l}\text { Exports } \\
\text { to Japan }\end{array}$ & $\begin{array}{l}\text { Export } \\
\text { Price to } \\
\text { Japan }\end{array}$ & $\begin{array}{l}\text { Exports } \\
\text { to } \\
\text { Others }\end{array}$ & $\begin{array}{l}\text { Export } \\
\text { Price to } \\
\text { Others }\end{array}$ & $\begin{array}{l}\text { Price Elasticity of } \\
\text { Domestic } \\
\text { Demand } \\
\text { (Absolute Value) }\end{array}$ & $\begin{array}{l}\text { degree-of- } \\
\text { market- } \\
\text { power } \\
\text { parameter }\end{array}$ & ESE E & $\begin{array}{l}\text { ESE per } \\
\text { unit }\end{array}$ \\
\hline & $\begin{array}{l}\text { (10 thousand } \\
\text { ton) }\end{array}$ & $(\$ / t)$ & $\begin{array}{l}10 \text { thousand } \\
\text { ton) }\end{array}$ & $(\$ / t)(1$ & $\begin{array}{l}0 \text { thousan } \\
\text { ton) }\end{array}$ & $d(\$ / t)$ & & & (million \$) & $(\$ / t)$ \\
\hline & Qt & $\mathrm{Pt}$ & $Q j$ & $\mathrm{Pj}$ & Qo & Po & $\mathrm{E}$ & $\begin{array}{c}\theta \\
=\mathrm{E}(1-\mathrm{Po} / \mathrm{Pj})\end{array}$ & $\begin{array}{c}\mathrm{ESE} \\
=(\mathrm{Pj}-\mathrm{Pt}) \mathrm{Qj}\end{array}$ & $\mathrm{Pj}-\mathrm{Pt}$ \\
\hline 1991 & 1,202 & 113 & 104 & 143 & 1,098 & 110 & 0.1 & 0.023 & 31.2 & 30 \\
\hline 1992 & 820 & 144 & 100 & 182 & 720 & 139 & 0.1 & 0.024 & 38.0 & 38 \\
\hline 1993 & 958 & 148 & 116 & 178 & 842 & 144 & 0.1 & 0.019 & 34.8 & 30 \\
\hline 1994 & 1,282 & 125 & 125 & 183 & 1,157 & 119 & 0.1 & 0.035 & 72.5 & 58 \\
\hline 1995 & 789 & 154 & 112 & 209 & 677 & 145 & 0.1 & 0.031 & 61.6 & 55 \\
\hline 1996 & 1,471 & 215 & 116 & 247 & 1,355 & 212 & 0.1 & 0.014 & 37.1 & 32 \\
\hline 1997 & 1,959 & 170 & 128 & 204 & 1,831 & 168 & 0.1 & 0.018 & 43.5 & 34 \\
\hline 1998 & 1,552 & 146 & 114 & 171 & 1,438 & 144 & 0.1 & 0.016 & 28.5 & 25 \\
\hline 1999 & 1,689 & 129 & 113 & 162 & 1,576 & 127 & 0.1 & 0.022 & 37.3 & 33 \\
\hline 2000 & 1,802 & 126 & 121 & 151 & 1,681 & 124 & 0.1 & 0.018 & 30.3 & 25 \\
\hline 2001 & 1,587 & 144 & 116 & 169 & 1,471 & 142 & 0.1 & 0.016 & 29.0 & 25 \\
\hline 2002 & 1,503 & 153 & 113 & 177 & 1,390 & 151 & 0.1 & 0.015 & 27.1 & 24 \\
\hline 2003 & 977 & 166 & 117 & 194 & 860 & 162 & 0.1 & 0.016 & 32.8 & 28 \\
\hline
\end{tabular}

Notes. The quantities and prices other than Japan's are from FAO (2000), and the elasticities from Ohga and Yanagishima (1996).

The Japan's data is from the Japanese Ministry of Finance. The export price to Japan is the Japanese import price net of transportation costs. The export price to others is calculated by $\mathrm{P}_{0}=(\mathrm{PtQt}-\mathrm{PjQj}) / \mathrm{Q} 0$.

Source: Fujii (2005). 
sumer financed" ESE values for Canadian dairy products are estimated to be about 84 million dollars.

Regarding "consumer financed" ESEs for price discrimination among export markets, Table 2 presents the AWB case. Estimated market power parameters indicate that the AWB's market power is not large because the estimates of $\theta$ are rather close to zero over time. However, because the export volume is large compared to the Canadian dairy products, the total ESEs for Australian wheat exports are about 39 million dollars per year, which is almost the same as the Canadian cheese case.

\section{CONCLUSIONS}

The Doha Round framework agreements state that all forms of export subsidies should be eliminated, which includes not only export subsidies through food aid and export credits, but also "consumer financed" ones through exporting STEs. Therefore, one needs a theoretical definition and practical measurements of "hidden" export subsidies unregulated under the current WTO rules.

This paper proposes a basic definition for the "consumer financed" export subsidy equivalent (ESE) created by STEs' price discrimination among export markets as well as price discrimination between export and domestic markets. Examples of calculated ESE values are shown using the Canadian dairy STE with price discrimination between export and domestic markets and the Australian wheat STE with price discrimination among export markets. The ESE proposed here would provide a useful measurement of "consumer financed" export subsidies.

\section{REFERENCES}

Alston J. M., and R. Gray 2000 State Trading versus Export Subsidies: The Case of Canadian Wheat. Joumal of Agricultural and Resource Economics, 25: 51-67

Brooks, H., and T. G. Schmitz 1999 Price Discrimination in the International Grain Trade: The Case of Canadian Wheat Board Feed Barley Exports. Agribusiness: An Intermational Joumal, 15: 313-322

Fujii, T. 2005 Measuring the Export Subsidy Equivalents Generated by the Australian Wheat Board. Graduation Thesis, Kyushu University, Fukuoka

FAO (Food and Agriculture Organization of the United Nations) 2000 FAOSTAT Statistics Database [online], available URL: http://apps.fao.org

Gropp, L., T., Hallam, and V. Manion 2000 Single-Desk Marketing: Assessing the Economic Arguments (Staff Research Paper), Productivity Commission, Canberra

McCorriston, S., and D. MacLaren 2000 State Trading in Agricultural Markets: A Conceptual Analysis OECD, OECD, Paris

Oga, K. and K. Yanagishima 1996 International Food and Agricultural Policy Simulation Model-User Guide (JIRCAS Working Report 1). JIRCAS, Tsukuba, Japan

Roningen, V. O., and P. M. Dixit 1989 Economic Implications of Agricultural Policy Reforms in Industrial Market Economies (Staff Paper No. AGES 89-36), U.S. Department of Agriculture, Economic Research Service, Washington, DC

Schluep, Isabelle 1999 The Law and Economics of "Consumer Only" Financed Export Subsidies: A Context for the WTO Panel on Canadian Dairy Pricing Policy, MS thesis, Cornell University, Ithaca, New York

Suzuki, N., and H. M. Kaiser 1998 Market Impacts of Japanese Rice Policies With and Without Supply Control. Agribusiness: An International Journal, 14: 355-362

Suzuki, N., J. E. Lenz and O. D. Forker 1993 A Conjectural Variations Model of Reduced Japanese Milk Price Supports. American Journal of Agricultural Economics, 75: 210-218 
Suzuki, N., J. Kinoshita, and H. M. Kaiser 2001 Measuring the Degree of Market Distortion through Price Discrimination for Hidden Export Subsidies Generated by State Trading Enterprises. Report on Economic Analysis and Investigation of State Trading Enterprises, Japan International Agricultural Council, Tokyo, pp. 11-27 